\title{
Hybrid approach: an alternative prior to corrective surgery in a patient with arch hypoplasia and complete atrioventricular septal defect
}

\author{
Arkus hipoplazisi ve komplet atriyoventriküler septal defekt olgusunda \\ korektif cerrahi öncesi alternatif hibrid yaklaşım
}

\author{
Mehmet Çelik ${ }^{1}$, Mahmut Gökdemir ${ }^{(2}{ }^{2}$, Nimet Cındık ${ }^{2}{ }^{2}$, Murat Özkan $\mathbb{1}^{3}$ \\ Institution where the research was done: \\ Başkent University Konya Medical and Research Center, Konya, Turkey
}

Author Affiliations:

'Department of Cardiovascular Surgery, Başkent University Konya Medical and Research Center, Konya, Turkey ${ }^{2}$ Department of Pediatric Cardiology, Bașkent University Konya Medical and Research Center, Konya, Turkey ${ }^{3}$ Department of Cardiovascular Surgery, Başkent University Faculty of Medicine, Ankara, Turkey

\begin{abstract}
The hybrid approach is mostly preferred in patients with hypoplastic left heart syndrome or univentricular physiology. Here, the hybrid approach is applied as a palliative procedure prior to corrective surgery in a patient with complete atrioventricular septal defect associated with arcus hypoplasia and results are discussed according to the literature.
\end{abstract}

Keywords: Bilateral pulmonary artery banding; complete atrioventricular septal defect; congenital heart disease; hybrid approach.

The "hybrid" approach which consists of bilateral pulmonary artery banding and ductus arteriosus (DA) stenting, and the "modified hybrid" approach which consists of bilateral pulmonary artery banding and prostaglandin E1 (PGE1) infusion are both alternative methods performed in patients with hypoplastic left heart syndrome (HLHS) and patients with risky functional univentricular cardiac physiology. ${ }^{[1-3]}$

Complete atrioventricular septal defect (AVSD) has an incidence of $2 / 1000$ live births, in which $70 \%$ of the patients have Down syndrome, and is an anomaly characterized by primum atrial septal defect (ASD), inlet ventricular septal defect (VSD), and common atrioventricular (AV) valve. Current treatment of AVSD includes corrective surgery before onset of
$\ddot{O} Z$

Hibrid yaklaşım çoğunlukla hipoplastik sol kalp sendromu ve benzeri tek ventrikül fizyolojisi olan hastalarda tercih edilir. Burada, hibrid yaklaşım, arcus hipoplazisi ile ilişkili atriyoventriküler septal defektli bir hastada düzeltici cerrahi öncesi palyatif işlem olarak uygulandı ve sonuçlar literatür 1şı̆̆ında tartışıldı.

Anahtar sözcükler: İki taraflı pulmoner arter band1; komplet atriyoventriküler septal defekt; doğuştan kalp hastalığı; hibrid yaklaşım.

pulmonary-vascular disease or congestive heart disease. Atrioventricular septal defect repair in the neonatal period and early infancy carries higher mortality and morbidity rates than in the late period. ${ }^{[4]}$ Recent surgical techniques, myocardial protection methods and developments in postoperative care have lowered mortality rates of the surgery performed at an early age. ${ }^{[4,5]}$ While results of a study by Vida et al ${ }^{[6]}$ on $8-12$ week old infants that underwent total repair surgery are promising, corrective surgery is avoided in younger babies due to the difficulties of repairing delicate valve tissue..$^{[7]}$

Our patient had a very large VSD, aortic arch hypoplasia with minor arch anomaly (common branching of the right brachiocephalic artery and the

Received: October 10, 2017 Accepted: January 09, 2018

Correspondence: Mehmet Çelik, MD. Başkent Üniversitesi Konya Uygulama ve Araştırma Merkezi, Kalp ve Damar Cerrahisi Anabilim Dalı, 42080 Selçuklu, Konya, Turkey. Tel: +90332-2570606 e-mail: mehmert1981@gmail.com 
left carotid artery-bovine trunk) arcus aorta hypoplasia (branching out of the truncus brachiocephalicus of the left main carotid artery), wide PDA, AV valve insufficiency (1-2 degree), and persistent left superior vena cava (SVC). The 52-day-old patient's heart failure continued and he developed poor overall state despite medical treatment; therefore we applied the hybrid (bilateral pulmonary artery banding and DA stent) approach to prepare the patient for corrective surgery.

\section{CASE REPORT}

Transthoracic echocardiography of the baby with Down syndrome showed complete AVSD, arch hypoplasia $(2.5-3 \mathrm{~mm})$, AV valve insufficiency (1-2 degree), PDA (bidirectional shunt), and left SVC. Intravenous $0.02 \mathrm{mcg} / \mathrm{kg} / \mathrm{min}$ PGE1 infusion was initiated. The patient whose heart failure did not improve, developed inadequate systemic perfusion and the "hybrid" (bilatral pulmonary artery banding and ductal stent implantation) prior to corrective surgery was performed.

The 52-day-old $3.4 \mathrm{~kg}$ patient was taken into surgery. Median sternotomy was performed under general anesthesia. The origins of branch pulmonary arteries were banded with $2 \mathrm{~mm}$ wide expanded polytetrafluoroethylene sliced off of a $4 \mathrm{~mm}$ vascular graft which were held in place with 6-0 prolene sutures

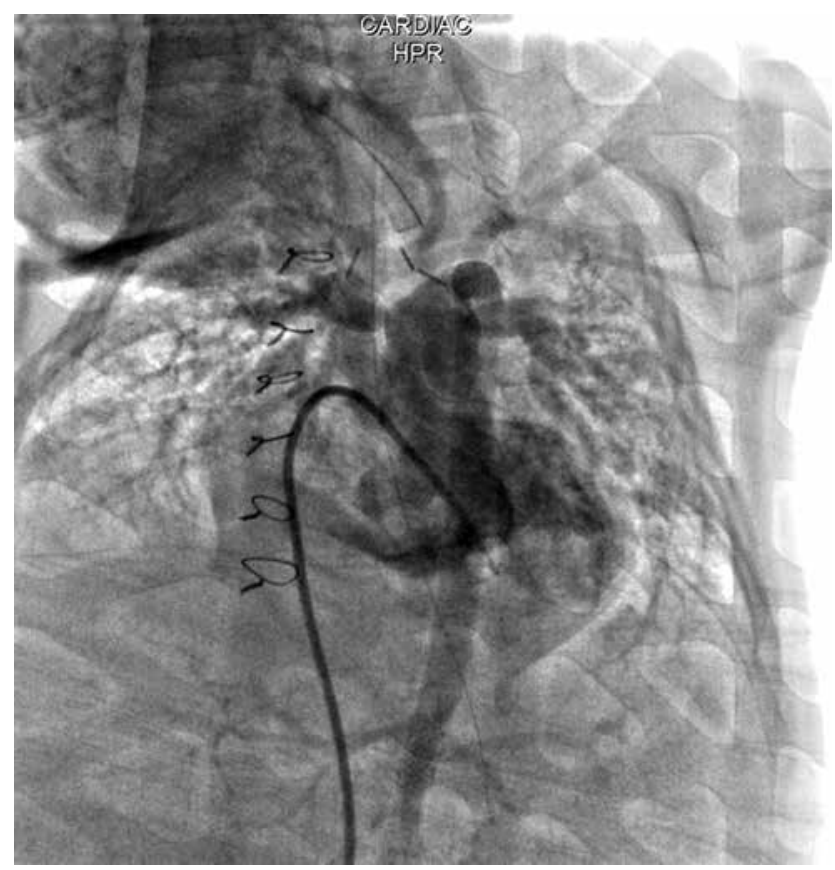

Figure 1. Angiography imaging after application of bilateral pulmonary banding and ductus arteriosus stent. to prevent migration. After the procedure, the patient inhaled $21 \%$ oxygen and the patient's oxygen saturation was approximately $65 \%$. There was a $10 \%$ increase in systemic arterial pressure.

The patient was taken into the angiography laboratory the next day. Measurements were made via the right femoral artery. The duct measured $2.1 \mathrm{~mm}$ at its narrowest. The descending aorta was measured as $5.8 \mathrm{~mm}$. A $4.5 \times 12 \mathrm{~mm}$ Rebel Bare stent (Boston Scientific, Two Scimed Place Maple Grove, MN, USA) was placed in the DA (Figure 1). Saturation increased to $89 \%$ when the patient inhaled $50 \%$ oxygen. Prostaglandin infusion was discontinued. The chest tube was removed on postoperative day 3 . The patient was extubated on postoperative day 21 . The patient was reintubated once during follow-up and extubated the next day. On postoperative day 61 , the patient was in poor condition and developed respiratory insufficiency. He was reintubated. He died on postoperative day 75 due to gram-negative sepsis despite of appropriate antibiotic treatment which was attributed to immune deficiency.

\section{DISCUSSION}

Atrioventricular septal defect is a congenital cardiac anomaly characterized by primum ASD, inlet VSD, and a common AV valve. The basis of treatment is to provide total correction before the development of pulmonary vascular disease or heart failure. Currently, the "hybrid" approach (bilateral pulmonary artery banding and DA stent) or the "modified hybrid" approach (bilateral pulmonary artery banding and PGE1 infusion) are alternatives to initial surgery mainly in patients with hypoplastic left heart syndrome and patients with univentricular heart physiology and associated anomalies that carry high surgical risk. High surgical risks in patients with HLHS and univentricular heart physiology include intact or restrictive atrial septum, severe preoperative acidosis $(\mathrm{pH}<7)$, renal failure, moderate-severe AV valve insufficiency, low birth weight, prematurity, preoperative cerebrovascular accident, and presence of extracardiac anomalies. ${ }^{[8,9]}$ Recently, although timing for corrective surgery of AVSD has been reduced to early infant stage, corrective surgery is not preferred in patients under two months of age. Vida et al. ${ }^{[6]}$ reported good results in 8-12 week-old patients who underwent corrective surgery. Although similar studies exist, our patient was younger than two months and had associated arch hypoplasia. Considering the high surgical risk of arch reconstruction and pulmonary banding, bilateral pulmonary artery 
banding and DA stenting was the initial plan for our patient. Severe hemodynamic problems were not encountered in postoperative follow-up. The patient died due to immunodeficiency-related sepsis during the corrective surgery planning period.

We believe that the hybrid approach (bilateral pulmonary artery banding and DA stent), aside from treatment of hypoplastic left heart syndrome and other high risk univentricular cardiac physiological anomalies, is an alternative palliative treatment that may also be performed preceding biventricular repair.

\section{Declaration of conflicting interests}

The authors declared no conflicts of interest with respect to the authorship and/or publication of this article.

\section{Funding}

The authors received no financial support for the research and/or authorship of this article.

\section{REFERENCES}

1. Guleserian KJ, Barker GM, Sharma MS, Macaluso J, Huang $\mathrm{R}$, Nugent AW, et al. Bilateral pulmonary artery banding for resuscitation in high-risk, single-ventricle neonates and infants: a single-center experience. J Thorac Cardiovasc Surg 2013;145:206-13.

2. Galantowicz M, Cheatham JP. Lessons learned from the development of a new hybrid strategy for the management of hypoplastic left heart syndrome. Pediatr Cardiol 2005;26:190-9.

3. Sakurai T, Kado H, Nakano T, Hinokiyama K, Shiose A, Kajimoto M, et al. Early results of bilateral pulmonary artery banding for hypoplastic left heart syndrome. Eur J Cardiothorac Surg 2009;36:973-9.

4. Ginde S, Lam J, Hill GD, Cohen S, Woods RK, Mitchell ME, et al. Long-term outcomes after surgical repair of complete atrioventricular septal defect. J Thorac Cardiovasc Surg 2015;150:369-74.

5. Wetter J, Sinzobahamvya N, Blaschczok C, Brecher AM, Grävinghoff LM, Schmaltz AA, et al. Closure of the zone of apposition at correction of complete atrioventricular septal defect improves outcome. Eur J Cardiothorac Surg 2000;17:146-53.

6. Vida VL, Tessari C, Castaldi B, Padalino MA, Milanesi O, Gregori D, et al. Early Correction of Common Atrioventricular Septal Defects: A Single-Center 20-Year Experience. Ann Thorac Surg 2016;102:2044-2051.

7. Backer CL, Stewart RD, Mavroudis C. Overview: history, anatomy, timing, and results of complete atrioventricular canal. Semin Thorac Cardiovasc Surg Pediatr Card Surg Annu 2007:3-10.

8. Gaynor JW, Mahle WT, Cohen MI, Ittenbach RF, DeCampli WM, Steven JM, et al. Risk factors for mortality after the Norwood procedure. Eur J Cardiothorac Surg 2002;22:82-9.

9. Stasik CN, Gelehrter S, Goldberg CS, Bove EL, Devaney EJ, Ohye RG. Current outcomes and risk factors for the Norwood procedure. J Thorac Cardiovasc Surg 2006;131:412-7. 